\title{
A study on relationship between CAMELS indexes and risk taking: A case study of Iranian banking industry
}

\author{
Mohammad Khodaei Valahzaghard ${ }^{\mathrm{a}^{*}}$ and Sahar Jabbari ${ }^{\mathrm{b}}$
}

\begin{abstract}
${ }^{a}$ Assist. Prof. \& Faculty Member, Department of Accounting, School of Management and Human Sciences, Tehran North Branch, Islamic Azad University (IAU), Tehran, Iran

${ }^{b}$ M.Sc. Student, Department of Accounting, School of Management and Human Sciences, Tehran North Branch, Islamic Azad University (IAU), Tehran, Iran

C H R O N I C L E

Article history:

Received October 29, 2012

Received in revised format

1 March 2013

Accepted 4 March 2013

Available online

March 62013

Keywords:

Risk taking

Risk management

Performance assessment

CAMELS indictors

A B S T R A C T

Among the activists of the money market, banks as the most important financial institutions undertake an important role in optimal appropriation of financial short-term resources. Furthermore, they allocate the short-term surplus funds to enterprises, which have a short-term need. Holding a main part of the funds in economy circulation, banks have a critical role in adjustment of economic relations. Banks are facing different types of risks in their daily operations. In the banking system, the CAMELS indictors are used to evaluate and rate of the performance of banks. The CAMELS rating model is one of the most effective systems of financial assessment in banks. Therefore, in this research, the effects of CAMELS indicators of banks on risk taking of Iranian banks are studied. The statistical population of the national banking system includes all governmental and private banks. The whole statistical population is studied as a research sample during 2006-2011. Taking into consideration the fact that the research data or section-bounded and time-bounded, a combinational regression analysis has been used. The results of the combinational regression analysis have supported the presence of a reverse and meaningful effect of the indicators of assets quality and sensitivity of market risk on risk taking in national banks. In addition, the results have supported the direct and meaningful effects of capital sufficiency and quality of profit-making on risk taking, however, the effects of the indicators of management quality and liquidity quality on risk taking have been rejected.
\end{abstract}

\section{Introduction}

Banking industry has been considered as the most important financial institutions undertake an important role in optimal appropriation of financial short-term resources (Khan, 1997; Al-Jarhi \& Iqbal, 2001). According to Dang (2011) banking supervision has become important because of significant loan losses and bank failures from the 1980s till now. CAMEL is one of the most important tools for investigating the safety and soundness of banks, and helps mitigate the potential risks, which could lead to bank failures.

Corresponding author. Tel: +98-912-3443139

E-mail addresses: m_khodaei@iau-tnb.ac.ir (M. Khodaei Valahzaghard)

(C) 2013 Growing Science Ltd. All rights reserved.

doi: $10.5267 /$ j.msl.2013.03.006 
Dang (2011) performed an empirical study of American International Assurance Vietnam (AIA) where the primary objective was to determine whether the CAMEL framework played a essential role in banking supervision or not. The study also identified the advantage as well as drawbacks, which the CAMEL system brings to AIA. The results concluded that CAMEL rating system was a useful supervisory tool in the U.S and CAMEL analysis method was beneficial as it is an internationally standardized rating and provided flexibility between on-site and off-site examination. Therefore, it was the primary model in evaluating banks' performance in AIA.

Babar and Zeb (2011) in an investigation investigated CAMEL rating system for banking industry in Pakistan and tried to find whether CAMELS system provide similar rating as PACRA system in assessing the performance of banks in Pakistan or not. According to Sarker (2005), Islamic banking as a new paradigm started in Bangladesh in 1983 and within few months, 6 more banks were built in that country and there has been a growing concerns on the goal of Islamic Shariah. Sarker (2005) investigated and made some recommendations on the more pertinent of some controversial issues on Islamic banking and suggested that micro, small, and medium enterprises (MSMEs) should get priority in the investment decisions of the Islamic banks.

Bikker and Metzemakers (2005) investigated on how bank provisioning behavior was associated with the business cycle, using 8000 bank-year data from 29 OECD countries over the past decade. Provisioning turned out to be substantially higher when GDP growth is lower, indicating increased riskiness of the credit portfolio when the business cycle turns downwards, which also increased the risk of a credit crunch. This effect was mitigated somewhat as provisions rise in times when earnings were higher, implying income smoothing, and loan growth was higher, indicating increased riskiness.

According to Gorton (2009), "the credit crisis was sparked by a shock to fundamentals, housing prices failed to rise, which led to a collapse of trust in credit markets. In particular, the repurchase agreement market in the U.S., estimated to be about \$12 trillion, larger than the total assets in the U.S. banking system ( $\$ 10$ trillion), became very illiquid during the crisis due to the fear of counterparty default, leaving lenders with illiquid bonds that they did not want, believing that they could not be sold. As a result, there was an increase in repo haircuts (the initial margin), causing massive deleveraging." Gorton (2009) studied this indirectly, by studying at the breakdown in the arbitrage foundation of the ABX.HE indices during the panic. They reported that when the ABX prices plummeted, the arbitrage relationships linking the credit derivatives linked to the index and the underlying bonds broke down because liquidity evaporated in the repo market.

Sinkey and Greenawalt (1991) performed a regression analysis and reported that loan-loss rates in 1987 were positively associated with loan rates, volatile funds, and loan volume from the preceding three years. Palvia et al. (2009) exploited a large panel of U.S. commercial banks to investigate the association between Chief Executive Officer (CEO) and Chairperson gender and bank risk-taking during the recent financial crisis. They postulated that female executives could constrain excessive risk-taking in commercial banks, and could thereby reduce default risk during periods of market stress. Their results also indicated that banks with female CEOs were more conservative and could hold higher levels of equity capital. The positive relationship between female CEOs and capital ratios was strongest in smaller banks, and weak or non-existent in larger banks.

Victoravich et al. (2011) investigated whether bank risk was a factor impacted by chief executive officer (CEO) power and equity incentives and the interaction between these factors over the period 2005-2009, which marked the unraveling of the financial crisis. CEO power was measured with an index, including five underlying variables such as CEO duality, a staggered board of directors, etc. They found that firm specific risk was decreasing with CEO power and equity incentives in the form of CEO equity compensation and future firm wealth. The findings recommended that when a CEO had more power, they could impact the board's decision-making to their benefit in reducing risk. They also detected that CEOs with more power took on higher levels of firm risk when they had 
greater levels of future firm wealth in the form of unexercisable options. Berger and Udell (2004) examined a new hypothesis that could help describe the procyclicality of bank lending. They tested this hypothesis and the results supported the hypothesis, although there were differences by bank size class. Laeven and Levine (2009) conducted the first empirical assessment of theories concerning risk taking by banks, their ownership structures, and national bank regulations. They reported that the same regulation had different influences on bank risk taking depending on the bank's corporate governance structure.

\section{The proposed study}

The CAMELS rating model is one of the most effective systems of financial assessment in banks. Therefore, in this research, the effects of CAMELS indicators of banks on risk taking of Iranian banks are studied. The statistical population of the national banking system includes all governmental and private banks. The whole statistical population is studied as a research sample during 2006-2011. Taking into consideration the fact that the research data or section-bounded and time-bounded, a combinational regression analysis has been used. The proposed model of this paper uses the following model,

$R T_{i, t}=\beta_{0}+\beta_{1} C A_{i, t}+\beta_{2} A Q_{i, t}+\beta_{3} M Q_{i, t}+\beta_{4} E Q_{i, t}+\beta_{5} L Q_{i, t}+\beta_{6} S M_{i, t}+\varepsilon_{i, t}$,

where $R T_{i, t}$ is risk taking, $C A_{i, t}$ represents capital adequacy, $A Q_{i, t}$ shows asset quality, $M Q_{i, t}$ is management quality, $E Q_{i, t}$ shows earning quality, $L Q_{i, t}$ demonstrates liquidity quality, $S M_{i, t}$ represents sensitivity market and finally $\varepsilon_{i, t}$ is the residuals. In this survey, to measure risk taking, Z-score is used where $\boldsymbol{Z}=(R O A+C A P) / \sigma_{R O A}$ and here $R O A$ represents return of assets, $C A P$ shows the ratio of capital to total assets and $\sigma_{R O A}$ shows standard deviation of $R O A$. Table 1 shows some of the basic statistics associated with the proposed study of this paper.

\section{Table 1}

Descriptive Statistics

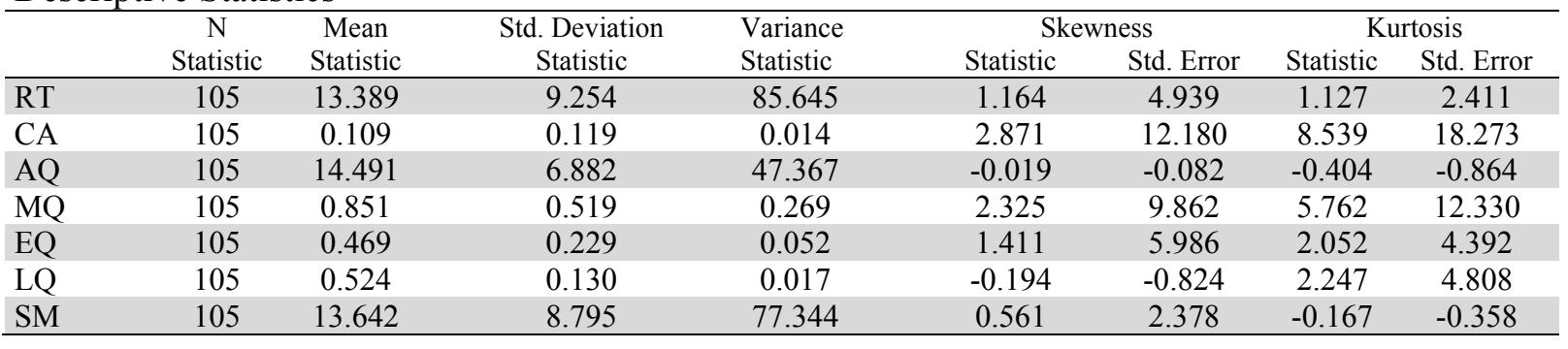

The results of Table present the implementation of three tests including Kolmogorev-Smirnov, Shapiro-Wilk and Jarque- bera tests. Based on the results of Table 2, we may assume that most independent variables are normally distributed.

\section{Table 2}

The results of Kolmogorev-Smirnov, Shapiro-Wilk and Jarque- bera tests

\begin{tabular}{|c|c|c|c|c|c|c|c|}
\hline & \multicolumn{3}{|c|}{ Jarque- bera test } & \multicolumn{2}{|c|}{ Shapiro-Wilk } & \multicolumn{2}{|c|}{ Kolmogorov-Smirnov } \\
\hline & $\mathrm{N}$ & Level of significance & Statistics & Level of significance & Statistics & Level of significance & Statistics \\
\hline $\mathrm{CA}$ & 105 & 0.000000 & 422.3392 & .000 & .604 & .000 & .274 \\
\hline $\mathrm{AQ}$ & 105 & 0.650731 & 0.859319 & .100 & .979 & .120 & .078 \\
\hline MQ & 105 & 0.000000 & 221.3878 & .000 & .700 & .000 & .230 \\
\hline EQ & 105 & 0.000000 & 49.10603 & .000 & .882 & .000 & .156 \\
\hline LQ & 105 & 0.000048 & 19.86938 & .004 & .961 & .049 & .087 \\
\hline SM & 105 & 0.062495 & 5.545340 & 0.006 & .964 & .200 & .064 \\
\hline
\end{tabular}

In addition, we need to whether we need to choose pooled or panel data and Table 3 shows the results of our survey. 


\section{Table 3}

The results of Chow and Hausman tests

\begin{tabular}{|c|c|c|c|c|c|c|c|c|}
\hline & $\begin{array}{c}\text { Chow } \\
\text { F-statistics }\end{array}$ & Sig, & Chi-square & Sig. & Results & $\begin{array}{l}\text { Hausman } \\
\text { Chi-Square }\end{array}$ & Error level & \\
\hline Pooled & 0.249478 & 0.9391 & 1.398981 & 0.9244 & Equal intercept & & & \\
\hline Panel & 27.20128 & 0.0000 & 212.15228 & 0.0000 & Unequal slope & 12.512864 & 0.0515 & Fixed effect \\
\hline
\end{tabular}

In addition, the results of F-statistics given in Table 4 indicate that we can assume a linear relationship and the result of Durbin-Watson shows that there is no auto correlation among residuals.

\section{Table 4}

The results of statistical tests

\begin{tabular}{lcccccc}
\hline & \multicolumn{2}{c}{ Linear relationship } & \multicolumn{2}{c}{ Durbin-Watson } & \multicolumn{2}{c}{ Residual test } \\
Model & F-statistics & Sig. & Obtained & Desired & J_B & P-Value \\
\hline 1 & 26.89926 & 0.000000 & 1.557797 & $1.5-2.5$ & 220.6803 & 0.000000 \\
\hline
\end{tabular}

Finally, we need to make sure there are no strong correlations among independent variables and Table 5 summarizes the results of our survey.

\section{Table 5}

The results of correlations among dependent variables

\begin{tabular}{|c|c|c|c|c|c|c|}
\hline & $\mathrm{CA}$ & $\mathrm{AQ}$ & MQ & EQ & LQ & SM \\
\hline $\mathrm{CA}$ & 1 & -.744 & .323 & -.349 & .335 & -.534 \\
\hline $\mathrm{AQ}$ & -0.704 & 1 & -.399 & .202 & -.304 & .554 \\
\hline MQ & 0.323 & -.399 & 1 & .282 & .214 & -.064 \\
\hline EQ & -0.349 & .202 & .282 & 1 & .305 & .661 \\
\hline LQ & 0.335 & -.304 & .214 & .305 & 1 & .197 \\
\hline SM & -0.534 & .554 & -.064 & .661 & .197 & 1 \\
\hline
\end{tabular}

Based on the results of Table 5, we could make sure that there are no strong correlations among independent variables.

\section{The results}

In this section, we present details of our findings on testing different hypotheses of this survey based on the implementation of regression analysis on Eq. (1). Table 6 summarizes the results of our survey on regression analysis.

\section{Table 6}

The summary of regression analysis

\begin{tabular}{lllcccc}
\hline Par. & Variable & Description & Coefficient & Std. error & t-student & P-value \\
\hline$\beta_{0}$ & c & Constant & 17.05538 & 2.009526 & 8.487266 & 0.0000 \\
$\beta_{1}$ & CA & Capital adequacy & 27.17168 & 9.867962 & 2.753524 & 0.0073 \\
$\beta_{2}$ & AQ & Asset quality & -0.089902 & 0.043996 & -2.043416 & 0.0443 \\
$\beta_{3}$ & MQ & Management quality & -0.520255 & 1.224855 & -0.424748 & 0.6722 \\
$\beta_{4}$ & EQ & Earning quality & 3.453903 & 1.840086 & 1.877034 & 0.0642 \\
$\beta_{5}$ & LQ & Liquidity quality & -6.186266 & 6.256310 & -0.988804 & 0.3258 \\
$\beta_{6}$ & SM & Sensitivity market & -0.241522 & 0.062409 & -3.869968 & 0.0002 \\
\hline
\end{tabular}

Important statistical tests including R-Square, F-value and Durbin-Watson are 0.89, 26.9 and 1.56, respectively. These results confirm the regression analysis and we can rely on the coefficients.

\subsection{Testing the first hypothesis: The relationship between CAMELS and RT}

Since $R T$ is the dependent variable in Eq. (1), we verify the following hypotheses,

$$
\left\{\begin{array}{l}
H_{0}: \beta_{\mathrm{CA}}, \beta_{\mathrm{AQ}}, \beta_{\mathrm{MQ}}, \beta_{\mathrm{EQ}}, \beta_{\mathrm{LQ}}, \beta_{\mathrm{SM}}=0 \\
H_{1}: \beta_{\mathrm{CA}}, \beta_{\mathrm{AQ}}, \beta_{\mathrm{MQ}}, \beta_{\mathrm{EQ}}, \beta_{\mathrm{LQ}}, \beta_{\mathrm{SM}} \neq 0
\end{array}\right.
$$


Since the coefficients of four variables, $C A, A Q, E Q$ and $S M$ are statistically significance with $\alpha=0.05$, we may somehow confirm the main hypothesis of this survey. There are also six subhypothesis associated with the proposed study of this paper, which are investigated accordingly. Note that the null hypothesis for all sub-hypotheses is that there is no relationship between the independent variable and dependent variable $(R T)$ and the alternative hypothesis states the opposite one.

\subsubsection{The first sub-hypothesis: the relationship between $R T$ and $C A$}

The first sub-hypothesis considers whether there is any meaningful relationship between RA and CA. The result of testing this hypothesis is as follows,

$$
\left\{\begin{array} { l } 
{ H _ { 0 } : \beta _ { C A , R T } = 0 } \\
{ H _ { 1 } : \beta _ { C A , R T } \neq 0 }
\end{array} \Rightarrow \left\{\beta=27.1716, T=2.753, t_{o b}>\left|t_{c}\right|, 2.753>|1.96,2.58|, p=.0073\right.\right.
$$

The result of t-student indicates that the relationship is statistically significance with $\alpha=0.05$. Therefore, the first sub-hypothesis is confirmed.

\subsubsection{The second sub-hypothesis: the relationship between $R T$ and $A Q$}

The second sub-hypothesis considers whether there is any meaningful relationship between $R A$ and $A Q$. The result of testing this hypothesis is as follows,

$$
\left\{\begin{array} { l } 
{ H _ { 0 } : \beta _ { A Q , R T } = 0 } \\
{ H _ { 1 } : \beta _ { A Q , R T } \neq 0 }
\end{array} \Rightarrow \left\{\beta=-0.0899, \quad T=-2.0434, t_{o b}>\left|t_{c}\right|,-2.0434>|1.96,2.58|, p=.0443\right.\right.
$$

The result of t-student indicates that the relationship is statistically significance with $\alpha=0.05$. Therefore, the second sub-hypothesis is accepted.

\subsubsection{The second sub-hypothesis: the relationship between $R T$ and $M Q$}

The third sub-hypothesis considers whether there is any meaningful relationship between $R A$ and $M Q$. The result of testing this hypothesis is as follows,

$$
\left\{\begin{array} { l } 
{ H _ { 0 } : \beta _ { M Q , R T } = 0 } \\
{ H _ { 1 } : \beta _ { M Q , R T } \neq 0 }
\end{array} \Rightarrow \left\{\beta=-0.5202, T=-0.4247, t_{o b}<\left|t_{c}\right|,-0.4247<|1.96,2.58|, p=.6722\right.\right.
$$

The result of t-student indicates that the relationship is not statistically significance with $\alpha=0.05$. Therefore, the null hypothesis is accepted, which means there is no relationship between management quality and risk taking.

\subsubsection{The fourth sub-hypothesis: the relationship between $R T$ and $E Q$}

The fourth sub-hypothesis considers whether there is any meaningful relationship between $R A$ and $E Q$. The result of testing this hypothesis is as follows,

$$
\left\{\begin{array} { l } 
{ H _ { 0 } : \beta _ { E Q , R T } = 0 } \\
{ H _ { 1 } : \beta _ { E Q , R T } \neq 0 }
\end{array} \Rightarrow \left\{\beta=3.4539, T=1.8770, t_{o b}<\left|t_{c}\right|, 1.8770<|1.96,2.58|, p=.0642\right.\right.
$$

The result of t-student indicates that the relationship is statistically significance only with $\alpha=0.10$. Therefore, the null hypothesis is rejected, which means there is a meaningful relationship between earning quality and risk taking.

\subsubsection{The fifth sub-hypothesis: the relationship between $R T$ and $L Q$}

The fifth sub-hypothesis considers whether there is any meaningful relationship between $R A$ and $L Q$. The result of testing this hypothesis is as follows, 
$\left\{\begin{array}{l}H_{0}: \beta_{L Q, R T}=0 \\ H_{1}: \beta_{L Q, R T} \neq 0\end{array} \Rightarrow\left\{\beta=-6.1862, T=-0.9888, t_{o b}>\left|t_{c}\right|,-0.9888<|1.96,2.58|, p=.3258\right.\right.$

The result of t-student indicates that the relationship is not statistically significance with $\alpha=0.05$. Therefore, the null hypothesis is accepted, which means there is not any meaningful relationship between liquidity quality and risk taking.

\subsubsection{The sixth sub-hypothesis: the relationship between RT and SM}

The fifth sub-hypothesis considers whether there is any meaningful relationship between $R A$ and $L Q$. The result of testing this hypothesis is as follows,

$$
\left\{\begin{array} { l } 
{ H _ { 0 } : \beta _ { S M , R T } = 0 } \\
{ H _ { 1 } : \beta _ { S M , R T } \neq 0 }
\end{array} \Rightarrow \left\{\beta=-0.2415, \quad T=-3.8699, t_{o b}>\left|t_{c}\right|,-3.8699>|1.96,2.58|, p=.0002\right.\right.
$$

The result of t-student indicates that the relationship is statistically significance with $\alpha=0.05$. Therefore, the null hypothesis is rejected, which means there is a meaningful relationship between sensitivity management and risk taking.

\section{Conclusion}

In this survey, we have investigated the relationship between CAMELS index and risk taking. The study also considered the relationship between risk taking and six independent variables including capital adequacy, asset quality, management quality, earning quality, liquidity quality and sensitivity market. The results of this survey have confirmed the main hypothesis. We hope the results of this survey could help banking industry to make better managerial decisions.

\section{References}

Al-Jarhi, M. A., \& Iqbal, M. (2001). Islamic banking: answers to some frequently asked questions. Occasional paper, (4).

Babar, H. Z., \& Zeb, G. (2011). Camels rating system for banking industry in pakistan: does CAMELS system provide similar rating as PACRA system in assessing the performance of banks in Pakistan? (Doctoral dissertation, Umeå University).

Berger, A. N., \& Udell, G. F. (2004). The institutional memory hypothesis and the procyclicality of bank lending behavior. Journal of Financial Intermediation,13(4), 458-495.

Bikker, J. A., \& Metzemakers, P. A. J. (2005). Bank provisioning behaviour and procyclicality. Journal of International Financial Markets, Institutions and Money, 15(2), 141-157.

Dang, U. (2011). The CAMEL rating system in banking supervision. A case study. Masters' thesis.

Gorton, G. B. (2009). Information, liquidity, and the (ongoing) panic of 2007 (No. w14649). National Bureau of Economic Research.

Khan, T. (1997). An analysis of risk sharing in Islamic finance with special reference to Pakistan. Loughborough University, Loughborough, PhD dissertation (unpublished).

Laeven, L., \& Levine, R. (2009). Bank governance, regulation and risk taking. Journal of Financial Economics, 93(2), 259-275.

Palvia, A., Peni, E., \& Vähämaa, S. (2009). Do female CEOs and chairs constrain bank risk-taking? Evidence from the financial crisis. risk, 174(7), 1-27.

Sarker, A. A. (2005). Islamic Banking in Bangladesh: Achievements and Challenges. Journal of Islamic Economics and Finance, 1(1).

Sinkey, J. F., \& Greenawalt, M. B. (1991). Loan-loss experience and risk-taking behavior at large commercial banks. Journal of Financial Services Research,5(1), 43-59.

Victoravich, L., Buslepp, W., Xu, T., \& Grove, H. (2011). CEO power, equity incentives, and bank risk taking. Available at SSRN 1909547. 